\title{
Porcine Splenic Hydrolysate has Antioxidant Activity in vivo and in vitro
}

\author{
Kyu-Ho Han, Kenichiro Shimada, Toru Hayakawa, Taek Joon Yoon ${ }^{1}$, and Michihiro Fukushima* \\ Department of Food Science, Obihiro University of Agriculture and Veterinary Medicine, Hokkaido 080-8555, Japan \\ ${ }^{1}$ Department of Food and Nutrition, Yuhan University, Bucheon 422-749, Korea
}

\begin{abstract}
The antioxidant capacity of porcine splenic hydrolysate (PSH) was studied in vitro and in vivo. Peptide hydrolysates were prepared, using the proteolytic enzyme Alcalase ${ }^{\circledR}$. The molecular weights of PSH were 37,666, 10,673, 6,029, and 2,918 g/ mol. Rats were fed a 5\% (w/v) PSH diet, instead of a casein diet, for $4 \mathrm{wk}$. The food intake, body weight gain, and liver weight of rats in the PSH group were similar to those in the control (CONT) group. There were no differences in the serum total cholesterol, triglyceride, total protein, or albumin levels between PSH and CONT groups. However, the level of in vivo hepatic lipid peroxidation in PSH group was significantly lower than that in CONT. In vivo hepatic catalase and glutathione peroxidase activities in the PSH group were significantly higher than those in the control group. The in vitro protein digestibility of PSH was lower than that of casein. The in vitro trolox equivalent antioxidant capacity of PSH was significantly higher than that of the peptide hydrolysate from casein. The in vitro radical scavenging activities of PSH were significantly higher than those of the peptide hydrolysate from casein. The present findings suggest that porcine splenic peptides improve the antioxidant status in rats by enhancing hepatic catalase and GSH-Px activities, and indicate a potential mechanism of radical scavenging activity during gastrointestinal passage.
\end{abstract}

Key words: porcine splenic hydrolysate, antioxidant, radical scavenging capacity, protein digestibility

\section{Introduction}

Dietary protein is one of the main energy sources and becomes a physiologically active component via the gastrointestinal tract. However, the antihypertensive, antioxidant, anticarcinogenic, and hypolipidemic properties of some proteins and peptides from plant and marine sources have been also studied (Di Bernardini et al., 2012; Latham 1999). Indeed, a few research investigations have focused on some peptides from milk casein, egg proteins, and animal muscle due to their antioxidant activities (Dávalos et al., 2004; Rival et al., 2001; Saiga et al., 2003). The antioxidant mechanism seems to be related to metal chelation, free radical scavenging, hydroperoxide reduction, and aldehyde adduction (Wang and Kurtz 2000). For example, casein-derived peptides have been shown to be capable of inhibiting enzymatic and non-enzymatic lipid peroxidation (Rival et al., 2001). An egg white hydroly-

*Corresponding author: Michihiro Fukushima, Department of Food Science, Obihiro University of Agriculture and Veterinary Medicine, Obihiro, Hokkaido 080-8555, Japan. Tel: +81-155-495557, Fax: +81-155-49-5577, E-mail: fukushim@obihiro.ac.jp sate has been also demonstrated to inhibit low density lipoprotein oxidation-induced copper ions and to quench radicals (Dávalos et al., 2004). Furthermore, Di Bernardini et al. (2012) reported that peptide hydrolysates of beef brisket sarcoplasmic proteins produced to scavenge DPPH radicals and chelate metal ions.

Recently, there is need for disposal of undesirable animal byproducts associated with the carbon footprint worldwide. The hydrolytic processing of animal proteins to produce new bioactive peptides might enable key question to be resolved effectively. The production might promote environmental sustainability as well as human health (Udenigwe and Howard 2012). In fact, an oligopeptide purified from porcine spleen (Polyerga ${ }^{\circledR}$ ) was has been used for up-regulating immune responses in human subjects (Borghardt et al., 2000). Moreover, preparation of enzymatic hydrolysates of proteins from animal resources has been introduced into the food industry to develop antioxidant peptides (Elias et al., 2008; Udenigwe and Howard, 2012). It is suggested that success in obtaining new antioxidant peptides from animal byproducts could positively affect meat-based food preservation (Udenigwe and Howard, 2012) because the operating environment of 
meat processing is easily affected by prooxidative factors such as light exposure, thermal treatment, metal contamination, and lipids (Elias et al., 2008). To the best of our knowledge, however, the antioxidant activity of porcine splenic byproduct has not been investigated.

The objective of the present investigation was to examine the antioxidant activity of a hydrolysate from a porcine spleen compared to hydrolysate of casein using an in vitro system to examine radical scavenging activities. Furthermore, the antioxidant effect of the porcine splenic hydrolysate was evaluated in normal rats.

\section{Materials and Methods}

\section{Preparation of porcine splenic hydrolysate}

The hydrolysate was prepared using the proteolytic enzyme Alcalase $^{\circledR}$ (Sigma-Aldrich, USA) (Dong et al., 2010), with slight modification. After slaughter, the fresh pig spleen was weighed, minced, and mixed with same volume of deionized water. The solution was adjusted to $\mathrm{pH}$ 8.0 and hydrolyzed using a protease at a 100 to 0.5 ratio (substrate/enzyme, v/v). The $\mathrm{pH}$ of the solution was constantly maintained during hydrolysis using $5 \mathrm{M} \mathrm{NaOH}$ at $55^{\circ} \mathrm{C}$ in a water bath for $18 \mathrm{~h}$. After hydroxylation, the mixture was boiled at $90^{\circ} \mathrm{C}$ for $10 \mathrm{~min}$ to inactivate the protease, followed by filtration to remove insoluble materials. Then the porcine splenic extract was spray-dried to a powder and kept at $4^{\circ} \mathrm{C}$ until analysis. For comparison of the antioxidant activities in vitro, hydrated peptide from casein (from bovine milk, Sigma-Aldrich) was also prepared under similar experimental conditions except for being freeze-dried.

\section{Determination of micronutrient and amino acid contents}

Protein, fat, carbohydrate, moisture, and ash contents in the splenic hydrolysate were measured by AOAC methods (1990). Amino acid analyses were conducted using the method of Fujiwara et al. (1987). In brief, the hydrolysates was hydrolyzed in $6 \mathrm{M} \mathrm{HCl}$ at $110^{\circ} \mathrm{C}$ for $24 \mathrm{~h}$, vacuum dried, reconstituted with $0.2 \mathrm{M} \mathrm{HCl}$, and filtered with a $0.45 \mu \mathrm{m}$ diameter filter (W-13-5; Tosoh, Japan). The composition of the hydrolyzed amino acids in the splenic hydrolysate was determined using an amino acid analyzer (Hitachi-8700, Hitachi, Japan).

\section{Determination of the molecular weight (MW) of the hydrolysate}

The molecular weights of splenic hydrolysates were determined by gel size exclusion chromatography. The hydrolysate at a concentration of $2 \mathrm{mg} / \mathrm{mL}$ in acetonitrile/ water/trifluoroacetic acid (30/70/0.1, v/v/v) was filtered with a syringe filter $(0.45 \mu \mathrm{m}$, Millipore) prior to injection. First, $50 \mu \mathrm{L}$ of the filtrate was loaded into a Shimadzu gel permeation chromatography (GPC) system (Japan) equipped with an LC-20AD pump (Shimadzu, Japan), and a diode array UV detector (SPD-M20A, Shimadzu, Japan). The analytical column (Superdex Peptide 10/300 GL, $10 \times 300$ mm, $13 \mathrm{~mm}$; GE Healthcare, USA) was eluted with acetonitrile/water/trifluoroacetic acid (30/ $70 / 0.1, \mathrm{v} / \mathrm{v} / \mathrm{v}$ ) at a flow rate of $0.5 \mathrm{~mL} / \mathrm{min}$ under the maximum operating pressure of $18 \mathrm{kgf} / \mathrm{cm}^{2}$ and monitored at $214 \mathrm{~nm}$. The calibration curve of MW was obtained using the following standards: bovine serum albumin (MW 69,000, Sigma-Aldrich), aprotinin (MW 6,512, SigmaAldrich), insulin chain A (MW 2,531, Sigma-Aldrich), angiotensin 2 (MW 1,046, Sigma-Aldrich), tuftsin (MW 500, Peptide Institute, Japan), and triglycine (MW189, Peptide Institute). The MW of the peptide from the splenic hydrolysate was determined using GPC Software (LCsolution GPC Ver. 1.21, Shimadzu).

\section{Trolox equivalent antioxidant capacity (TEAC)}

The total antioxidant status of the hydrated peptides from casein and porcine spleen was determined using a commercial kit (NX 2332, Randox Laboratories Ltd., UK), based on the 2,2'-azinobis(3-ethylbenzothiazoline-6sulfonate) radical cation decolorization assay. Results were expressed as micromoles of Trolox per $\mathrm{g}$ of each sample.

\section{1,1-Diphenyl-2-picrylhydrazyl (DPPH) radical scavenging test}

For stock solutions, each sample (100 mg) was dissolved in $10 \mathrm{~mL}$ of deionized water. Then $300 \mathrm{~mL}$ of the solution, which contained different concentrations of stock solution samples (0-3 mg/assay), was added to $900 \mathrm{~mL}$ of a mixture consisting of $400 \mathrm{mM}$ DPPH (Wako, Japan) and $20 \%(\mathrm{v} / \mathrm{v})$ ethanol in $0.2 \mathrm{M}$ 2-( $N$-morpholino)ethanesulfonic acid buffer ( $\mathrm{pH}$ 6.0). The optical density (OD) of the solution was then measured at $520 \mathrm{~nm}$ using a spectrophotometer (UV-1600, Shimadzu) (Brand-Williams et al., 1995). Trolox (0.2 mM, Sigma-Aldrich) was used as the standard.

\section{Superoxide dismutase (SOD)-like activity}

The SOD-like activities of samples were investigated using a commercial kit (AB-2970 CLETA-S, ATTO, Japan). This method is based on the luminescence (LC) 
generated by MPEC (ATTO) with the superoxide anions generated by the xanthine-xanthine oxidase system. LC was measured using a luminometer (AB-2350, ATTO).

$$
\begin{aligned}
& \text { SOD-like activity }(\%)= \\
& {\left[1-\left(\mathrm{LC}_{\text {sample positive }}-\mathrm{LC}_{\text {sample negative }}\right) /\right.} \\
& \left.\left(\mathrm{LC}_{\text {control positive }}-\mathrm{LC}_{\text {control negative }}\right)\right] \times 100,
\end{aligned}
$$

where $\mathrm{LC}_{\text {sample positive }}$ represents the total $\mathrm{LC}$ count of the sample solution and $\mathrm{LC}_{\text {sample negative }}$ is that for the sample solution not containing xanthine oxidase. $\mathrm{LC}_{\text {control }}$ represents the total LC count of the control solution without any sample or enzyme.

\section{Ferric thiocyanate test}

Peroxyl radical scavenging activity of each sample was measured by the method of López-Alarcón and Lissi (2005). In brief, $100 \mathrm{~mL}$ of a $1 \%$ (w/v) hydrolysate sample was added to a solution of $15 \mathrm{~mL}$ of $600 \mathrm{mM} 2,2$ azobis-(2-amidinopropane)dihydrochloride (AAPH) and $1 \mathrm{~mL}$ of $60 \mathrm{mM}$ pyrogallol red (both from Sigma-Aldrich) in phosphate-buffered saline (PBS) buffer (pH 7.0) with $30 \%(\mathrm{v} / \mathrm{v})$ ethanol. Then the mixture was incubated in a water bath at $37^{\circ} \mathrm{C}$ for $2 \mathrm{~h}$, and the absorbance was measured at $540 \mathrm{~nm}$. The radical scavenging activity was calculated as follows:

$$
\begin{aligned}
& \text { Reduction }(\%)=100-\left[\left(\mathrm{OD}_{\text {control }}-\mathrm{OD}_{\text {control blank }}\right) /\right. \\
& \left.\left(\mathrm{OD}_{\text {sample }}-\mathrm{OD}_{\text {sample blank }}\right)\right] \times 100,
\end{aligned}
$$

$\mathrm{OD}_{\text {sample }}$ represents the absorption of the sample solution and $\mathrm{OD}_{\text {control }}$ that for the control solution not containing the sample. Both $\mathrm{OD}_{\text {blank }}$ are for the blank solution not containing AAPH.

\section{Chelation of ferrous ions}

The chelation of ferrous ions by each sample was assayed according to the method of Dinis et al. (1994). In brief, a $1 \%(\mathrm{w} / \mathrm{v})$ sample was mixed with $2 \mathrm{mM} \mathrm{FeCl}_{2}$. The reaction was initiated by the addition of $5 \mathrm{mM}$ ferrizine (Sigma-Aldrich). The mixture was shaken vigorously and left to stand for $10 \mathrm{~min}$. The absorbance of the solution was then measured at $562 \mathrm{~nm}$ using a spectrophotometer.

$$
\begin{aligned}
& \text { Inhibition }(\%)= \\
& {\left[\mathrm{OD}_{\text {control }}-\left(\mathrm{OD}_{\text {sample }}-\mathrm{OD}_{\text {blank }}\right)\right] / \mathrm{OD}_{\text {control }} \times 100}
\end{aligned}
$$

where $\mathrm{OD}_{\text {sample }}$ represents the absorption of the sample solution, $\mathrm{OD}_{\text {control }}$ that for the control solution not containing the sample, and $\mathrm{OD}_{\text {blank }}$ is that for the blank solution not containing ferrizine.

\section{Protein digestibility}

The in vitro protein digestibility of the porcine splenic hydrolysate and the casein was evaluated by the $\mathrm{pH}$-shift method using the multi-enzyme technique (AOAC, 1990). Based on Kjeldahl nitrogen at a concentration of $1 \mathrm{mg} /$ $\mathrm{mL}$ in distilled water each sample was adjusted to $\mathrm{pH} 8.0$ at $37^{\circ} \mathrm{C}$ in a water bath. Then a multi-enzyme mixture, freshly prepared using trypsin, $\alpha$-chymotrypsin, and peptidase (all from Sigma-Aldrich), was added to the solution for $10 \mathrm{~min}$ at $37^{\circ} \mathrm{C}$ followed by bacterial protease (SigmaAldrich, USA) at $55^{\circ} \mathrm{C}$ for $9 \mathrm{~min}$. Following this the temperature was changed back to $37^{\circ} \mathrm{C}$ for $1 \mathrm{~min}$. Finally the reduction in $\mathrm{pH}$ of the sample from $\mathrm{pH} 8.0$ was monitored after $20 \mathrm{~min}$ of incubation. The protein digestibility was calculated as follows:

$\%$ Digestibility $=234.84-22.56(\mathrm{X})$,

where $X=p H$ reduction at $20 \mathrm{~min}$.

\section{Animals and diets}

Male F344/DuCrj rats (13 wk of age) were obtained from Charles River Japan (Japan). The animals were kept in plastic cages at a temperature of $23 \pm 1{ }^{\circ} \mathrm{C}$ and a relative humidity of $60 \pm 5 \%$ with a $12 \mathrm{~h}$ light-dark cycle. All animal studies conformed to the principles of the NIH Guide for the Care and Use of Laboratory Animals. This experimental animal procedure was approved by the Animal Experiment Committee of Obihiro University of Agriculture and Veterinary Medicine. Rats were acclimated for 1 wk and given access to food and water ad libitum. Then the animals were randomly divided into two diet groups $(n=5)$ with no significant difference in body weight at the start of the experiment. The control group (CONT) was fed a diet based on the AIN-93G semi-purified rodent diet containing $200 \mathrm{~g} / \mathrm{kg}$ of casein, $100 \mathrm{~g} / \mathrm{kg}$ of sucrose, $3.5 \mathrm{~g} /$ $\mathrm{kg}$ of mineral mixture, $1.0 \mathrm{~g} / \mathrm{kg}$ of vitamin mixture, 549.5 $\mathrm{g} / \mathrm{kg}$ of $\alpha$-corn starch, $50 \mathrm{~g} / \mathrm{kg}$ of cellulose, $3 \mathrm{~g} / \mathrm{kg}$ of Lcystine, $70 \mathrm{~g} / \mathrm{kg}$ of soybean oil, $2.5 \mathrm{~g} / \mathrm{kg}$ of choline bitartrate, and $0.014 \mathrm{~g} / \mathrm{kg}$ of tert-butyl hydroquinone for $4 \mathrm{wk}$. The treatment group was fed a diet containing $50 \mathrm{~g} / \mathrm{kg}$ of porcine splenic hydrolysate (PSH) instead of casein for 4 wk. Body weight and food consumption were recorded weekly and daily, respectively. At the end of the experimental period, the rats were anesthetized with Nembutal 
(sodium pentobarbital, $40 \mathrm{mg} / \mathrm{kg}$ of body weight; Abbott Laboratories, USA) and killed without fasting. The blood was drawn quickly and the biochemical parameters were determined using a Toshiba TBA-120FR autoanalyzer (Toshiba Medical Systems Corp., Japan). The livers were frozen $\left(-80^{\circ} \mathrm{C}\right)$ in tubes before further analysis.

\section{Hepatic malondialdehyde (MDA) and glutathione} (GSH) levels, and antioxidant enzyme activities

The degree of oxidation was immediately measured by thiobarbituric acid reactive substances assay (Ohkawa et al., 1979). Liver samples were homogenized in 10 volumes of PBS ( $\mathrm{pH}$ 7.4). Protein concentrations were determined by Lowry assay (Bio-Rad, CA). The hepatic GSH level was analyzed by the method of Cohn and Lye (1966). Hepatic catalase activity was analyzed by the method of Aebi (1984) based on measuring the rate of $\mathrm{H}_{2} \mathrm{O}_{2}$ depletion using a spectrophotometer at $240 \mathrm{~nm}$. Glutathione peroxidase (GSH-Px) activity was analyzed by the method of Lawrence and Burk (1976). Glutathione reductase (GSH-R) and glutathione-S-transferase (GST) activities were analyzed by the methods of Worthington and Rosemeyer (1976) and Habig et al. (1974), respectively.

\section{Statistics}

The results reported here are the means of at least three measurements (in vitro) and the standard deviations (SD). Significant differences between two groups (in vivo and in vitro) were determined by Student's $t$-test. Analyses were performed using PASW Statistics 17.0 software (SPSS Institute, USA).

\section{Results}

\section{Micronutrient and amino acid contents and MW}

Protein, fat, carbohydrate, moisture, and ash contents in the splenic hydrolysate were as follows $(\mathrm{g} / 100 \mathrm{~g})$ : protein (calculated by multiplying the nitrogen contents by 6.25 ), 79.9; fat, 0.1; carbohydrate, 4.1; moisture, 8.3; ash, 7.6. The amino acid composition in the splenic hydrolysate was similar to that of casein (Table 1), the data for which were obtained from the Food Composition Database in Japan (http://fooddb.jp/). However, Tyr, Pro and Glu levels in the splenic hydrolysate were lower than those in casein, whereas those of Ala, Gly, and Cys in PSH were higher than in casein. Fig. 1 shows the molecular weight distribution from high to intermediate molecular weights of the splenic hydrolysate, which indicated that PSH was successfully treated by enzymatic hydrolysis. The main
Table 1. Amino acid compositions of casein and porcine splenic hydrolysate

\begin{tabular}{cccccc}
\hline \hline \multirow{2}{*}{$\begin{array}{c}\text { Amino } \\
\text { acid }\end{array}$} & \multirow{2}{*}{ MW } & \multicolumn{2}{c}{ Casein* $^{*}$ Splenic hydrolysate } \\
\cline { 3 - 6 } & & $\mathrm{g} 100 \mathrm{~g}^{-1}$ & mol\% & $\mathrm{g} 100 \mathrm{~g}^{-1}$ & mol\% \\
\hline Arg & 174.2 & 3.30 & 2.67 & 3.64 & 3.62 \\
Lys & 146.2 & 7.10 & 6.85 & 5.89 & 6.99 \\
His & 155.2 & 2.70 & 2.45 & 2.23 & 2.49 \\
Phe & 165.2 & 4.50 & 3.84 & 3.23 & 3.39 \\
Tyr & 181.2 & 5.00 & 3.89 & 2.32 & 2.22 \\
Leu & 131.2 & 8.40 & 9.03 & 6.46 & 8.54 \\
Ile & 131.2 & 4.90 & 5.27 & 3.06 & 4.04 \\
Met & 131.2 & 2.60 & 2.79 & 1.57 & 2.07 \\
Val & 117.1 & 6.00 & 7.23 & 4.62 & 6.84 \\
Ala & 89.1 & 2.70 & 4.27 & 4.82 & 9.38 \\
Gly & 75.1 & 1.60 & 3.00 & 4.99 & 11.5 \\
Pro & 115.1 & 10.0 & 12.3 & 3.72 & 5.60 \\
Glu & 147.1 & 19.0 & 18.2 & 10.2 & 12.0 \\
Ser & 105.1 & 4.60 & 6.17 & 3.49 & 5.76 \\
Thr & 119.1 & 3.70 & 4.38 & 3.31 & 4.82 \\
Asp & 133.1 & 6.30 & 6.67 & 7.10 & 9.25 \\
Trp & 204.1 & 1.10 & 0.76 & 0.87 & 0.74 \\
Cys & 240.3 & 0.43 & 0.25 & 0.97 & 0.70 \\
\hline Total & & 93.9 & 100 & 72.5 & 100 \\
\hline
\end{tabular}

*Data from Food Composition Database in Japan (see http:// fooddb.jp/)

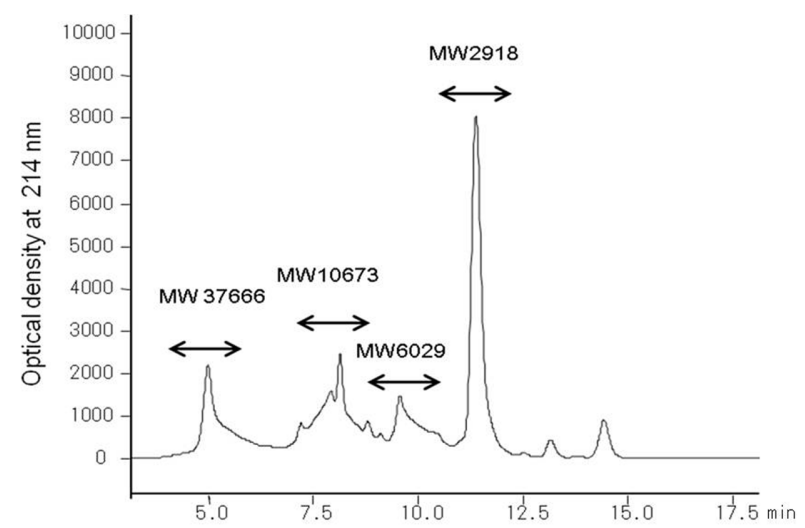

Fig. 1. The molecular weights of splenic hydrolysates. They were determined by gel size exclusion chromatography.

MWs obtained from the splenic hydrolysate were 37,666 , $10,673,6,029$, and 2,918 .

\section{In vitro study}

\section{TEAC, radical scavenging activity, ferrous ion} chelating activity and protein digestibility

The total antioxidant potential in each sample measured by Randox-TEAC is shown in Table 2. The antioxidant potential in splenic hydrolysate was higher than in casein hydrolysate. The Trolox equivalent of the splenic hydrolysate was approximately $3 \mu \mathrm{mol}$ per g of powder, which 
Table 2. Trolox equivalent antioxidant capacity (TEAC), radical scavenging activities, ferrous ion chelating activity and protein digestibility of casein and porcine splenic hydrolysates in vitro

\begin{tabular}{cccc}
\hline \hline & & Group & \multirow{2}{*}{$P$ value } \\
\cline { 2 - 3 } & Casein hydrolysate & Spleen hydrolysate & \\
\hline TEAC $(\mu \mathrm{mol}$ TE/g) & $1.20 \pm 1.13$ & $3.18 \pm 0.50$ & 0.05 \\
Peroxyl radical scavenging activity $(\%)^{*}$ & $\mathrm{ND}$ & $41.0 \pm 2.1$ & - \\
$\mathrm{O}_{2}^{-}$radical scavenging activity $(\%)^{*}$ & $18.3 \pm 4.4$ & $80.3 \pm 1.1$ & $<0.001$ \\
${\text { Ferrous ion chelating activity }(\%)^{*}}^{\text {Protein digestibility }(\mathrm{g} / 100 \mathrm{~g})}$ & $98.5 \pm 0.5$ & $70.1 \pm 1.0$ & $<0.001$ \\
\hline
\end{tabular}

ND, not detected. $* 1 \%$ hydrolysate sample was added to each assay.

was three-fold that of the casein hydrolysate. DPPH radical scavenging activities of the casein hydrolysate and splenic hydrolysate were expressed as the OD of $0.4 \mathrm{mM}$ DPPH solution (Fig. 2). The splenic hydrolysate had a significantly $(p<0.05)$ lower effective dose $\left(\mathrm{EC}_{50}\right)$ for scavenging $50 \%(\mathrm{w} / \mathrm{v})$ of $\mathrm{DPPH}$ radicals $\left(\mathrm{EC}_{50}=1.16 \mathrm{mg} /\right.$ assay) than the casein hydrolysate $\left(\mathrm{EC}_{50}=1.67 \mathrm{mg} / \mathrm{assay}\right)$. The Trolox equivalents (pmol/assay) of the casein hydrolysate and splenic hydrolysate for the DPPH radical scavenging activity were 1.69 and 16.00 , respectively. $\mathrm{O}_{2}^{-}$radical scavenging activity (SOD-like activity) of the hydrolysates was significantly $(p<0.05)$ higher in the order splenic hydrolysate $>$ casein hydrolysate (Table 2 ). The antioxidant capacity of the splenic hydrolysate against peroxyl radicals was $40 \%$. However, in $1 \%(\mathrm{w} / \mathrm{v})$ casein hydrolysate, the peroxyl radical scavenging activity was not detected (Table 2). Table 2 also shows the $\mathrm{Fe}^{2+}$ ion

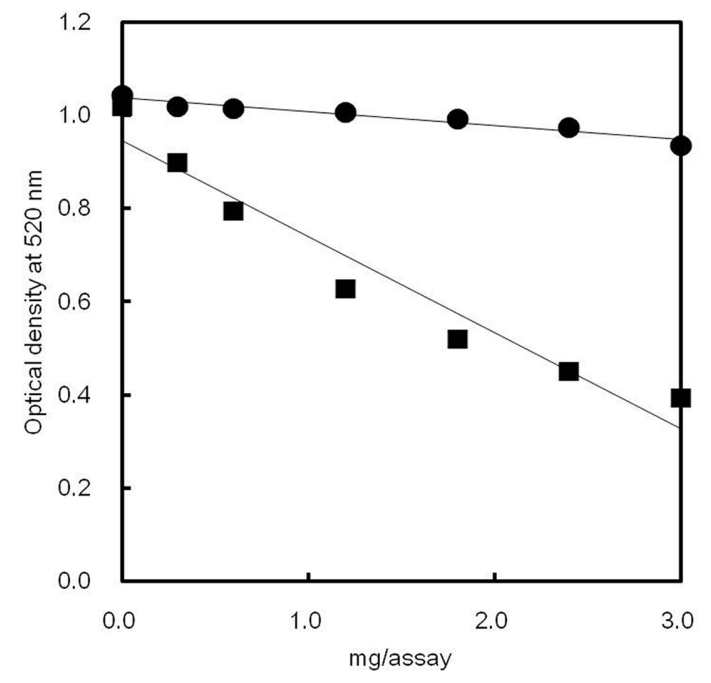

Fig. 2. Antioxidant activity in in vitro 1,1-diphenyl-2-picrylhydrazyl (DPPH) radical scavenging test. The data are expressed as the means of at least three measurements and the standard deviations (SD). Significant differences were determined using Student's $t$-test $(n=3)$. All concentration were significantly different at $p<0.05$ except $0 \mathrm{mg} /$ assay. (๑) and (ם) are for casein hydrolysate and PSH hydrolysate, respectively. chelating activities (\%) of the casein hydrolysate and splenic hydrolysate at the $1 \%$ concentration level. The activity was significantly $(p<0.05)$ higher in the order casein hydrolysate $>$ splenic hydrolysate. The in vitro protein digestibilities of the casein and the splenic hydrolysate by gastrointestinal digestive enzymes were 89.9 and $69.6 \%$, respectively (Table 2).

\section{In vivo study}

\section{Food intake, body weight, blood biochemical parameters}

The food intake, body weight gain and liver weight of rats in the PSH group were not significantly different from those in the CONT group (Table 3). Furthermore, the serum total cholesterol, triglyceride, total protein, and albumin levels, and blood leukocyte concentration in the $\mathrm{PSH}$ group were similar to those in the CONT group.

\section{Hepatic MDA and GSH levels, and antioxidant enzyme activities}

The liver MDA level in the SPH group was significantly $(p<0.05)$ lower than that in the CONT group, though there was no significant difference in the hepatic GSH level between the two groups (Table 3). Hepatic catalase and GSH-Px activities in the PSH group were significantly $(p<0.05)$ higher than those in the CONT group. However, hepatic GST and GR activities in the PSH group were not significantly different between the CONT group and PSH group (Table 3).

\section{Discussion}

The oxidative stability of biological tissue is related to the balance between antioxidant and prooxidative factors. The production of reactive oxygen species (ROS) such as superoxide anions, singlet oxygen, hydrogen peroxide and free radicals in living species during enzymatic reactions and xenobiotic metabolism leads to an increase in 
Table 3. Body weight, food intake, liver weight, blood biological parameters, hepatic TBARS and glutathione concentrations, and hepatic antioxidant enzyme activities

\begin{tabular}{|c|c|c|c|}
\hline & \multicolumn{2}{|c|}{ Dietary group } & \multirow{2}{*}{$P$ value } \\
\hline & CONT & PSH & \\
\hline Body weight gain (g/4 wk) & $32.1 \pm 3.2$ & $34.2 \pm 4.2$ & 0.392 \\
\hline Food intake (g/4 wk) & $507 \pm 34$ & $495 \pm 29$ & 0.567 \\
\hline Liver weight $(\mathrm{g})$ & $7.08 \pm 0.61$ & $6.98 \pm 0.33$ & 0.231 \\
\hline Serum total cholesterol $(\mathrm{mmol} / \mathrm{L})$ & $2.07 \pm 0.18$ & $2.00 \pm 0.07$ & 0.449 \\
\hline Serum triglyceride $(\mathrm{mmol} / \mathrm{L})$ & $1.08 \pm 0.23$ & $1.06 \pm 0.12$ & 0.906 \\
\hline Serum total protein $(\mathrm{g} / \mathrm{L})$ & $80.5 \pm 1.6$ & $80.5 \pm 0.8$ & 0.941 \\
\hline Serum albumin $(\mathrm{g} / \mathrm{L})$ & $50.0 \pm 1.2$ & $50.0 \pm 0.4$ & 0.918 \\
\hline Blood leukocytes $\left(10^{3} / \mathrm{mL}\right)$ & $3.00 \pm 0.19$ & $2.65 \pm 0.34$ & 0.076 \\
\hline Liver TBARS (nmol/mg protein) & $0.483 \pm 0.074$ & $0.392 \pm 0.016$ & 0.026 \\
\hline Liver GSH ( $\mu \mathrm{mol} / \mathrm{g}$ liver $)$ & $4.15 \pm 0.32$ & $4.49 \pm 0.48$ & 0.223 \\
\hline Liver catalase (U/mg protein) & $49.2 \pm 3.2$ & $58.2 \pm 4.8$ & 0.008 \\
\hline Liver GSH-Px (mU/g protein) & $292 \pm 13$ & $353 \pm 53$ & 0.038 \\
\hline Liver GST (mU/mg protein) & $208 \pm 15$ & $205 \pm 16$ & 0.770 \\
\hline Liver GSH-R (mU/mg protein) & $57.7 \pm 2.0$ & $60.5 \pm 5.7$ & 0.329 \\
\hline
\end{tabular}

Values are expressed as means \pm standard deviations for five rats. Significant differences were determined using Student's $t$-test.

lipid oxidation and subsequent cell injury (Cadenas and Davies, 2000). Biological tissue, especially liver cells, guards against ROS via a protective mechanism in which the potential toxicity of the partial products of oxygen is minimized by catalytic actions of SOD, catalase, GSH-Px, and other enzymes (Cadenas and Davies, 2000). However, the oxidative stress in living species gradually increases dependant on aging (Cadenas and Davies, 2000). For these reasons, constant intake of antioxidant agents from a proper diet is required to reduce or delay this aging-dependent loss. To date, there is little information on evaluation of the efficacy and detailed mechanisms of physiological functions of meat-based antioxidant peptides, especially against oxidative stress, in animal studies. However, Nazeer et al. (2012) recently examined the antioxidant effect of a peptide purified from a fish muscle hydrolysate in rats with ethanol-induced oxidative stress, showing increases in catalase and SOD activities in an erythrocyte lysate by orally injecting the peptide. Similarly, in this study, the hepatic MDA level in the PSH group was lower than in the CONT group, which might have been due to the increases in the hepatic catalase and GSH-Px activities. Both enzymes deactivate hydroperoxide into water, and GSH-Px also reduces organic peroxides into their corresponding alcohols (Cadenas and Davies, 2000). Thus it is considered that providing dietary PSH to rats might achieve antioxidant activity enhancing those systems.

The underlying mechanism for the health-promoting activity of the peptide mixture of porcine spleen in the animal might be free radical scavenging and hydroperox- ide reduction. In this study, various free radical scavenging capacities of the splenic hydrolysate were comparable to those of casein when hydrolyzed with Alcalase $^{\circledR}$. Those activities were in accord with the results of TEAC assays, in which the Trolox equivalent value of the splenic hydrolysate was approximately three times higher than those of the hydrolysate of casein. However, the ferrous metal chelation activity in the casein hydrolysate was stronger than in the porcin splenic hydrolysate. The biological functions of the parent proteins or free amino acids seem to be more limited than after hydrolysis (Gill et al., 1996), suggesting roles for specific peptide sequences. The porcine splenic hydrolysate had a higher Cys residue content than casein. This amino acid residue exhibits substantial radical generation in vitro (Hernandez-Ledesma et al., 2005). However, most peptides are normally degraded into dipeptide or amino acid during gastrointestinal digestion. Thus, it is profoundly difficult for a bioactive peptide, especially a high-molecular-weight peptide, to be directly linked to the antioxidant system of hepatic cells as in vitro free radical scavenging activity. In this study, the in vitro protein digestibility of the porcine splenic hydrolysate was lower than that of casein. Excessive intakes of carbohydrates raise the susceptibility to oxidative stress, affecting the biological tissue antioxidant network (Bae et al., 2001). Some antioxidants such as phytochemicals may play important roles in limiting potential postprandial oxidative stress by reducing radical generation during gastrointestinal passage (Halliwell et al., 2000; Sies et al., 2005; Stahl et al., 2002). Halliwell et al. (2000) suggested that the gastrointestinal tract is a major location 
of antioxidant action. Owing to the limited absorption of the splenic hydrolysate, therefore, the antioxidant properties of PSH might be exerted mainly in the gastrointestinal tract.

Although peptides and hydrolysates are available as antioxidants in food additives, the potential safety issue of allergenicity still remains. This is because that, when high-molecular-weight polypeptides are absorbed via tight junctions, they might become specific allergy antigens (Gardner, 1998). However, it has been reported that some peptides might reduce allergic reactions in atopic subjects and improve mucosal immunity in the gastrointestinal tract (Korhonen and Pihlanto, 2003). Furthermore, Poly$\operatorname{erga}^{\circledR}$, which is an oligopeptide purified from porcine spleen, was reported to be effective in up-regulating immune responses in human subjects (Borghardt et al., 2000). The immunomodulatory actions of some peptides have been evaluated by lymphocyte proliferation, natural killer (NK) cell activity, antibody synthesis, and cytokine regulation (Fitzgerald and Murray, 2006; Horiguchi et al., 2005). However, the splenic NK cell activity did not significantly differ between the CONT and PSH groups in this study, which suggested that PSH did not induce an immune response in the animals (data not shown). This observation might be attributable to the differences between purified hydrolysates (Polyerga ${ }^{\circledR}$ ) and crude hydrolysates, or the lowered digestibility of the splenic hydrolysate. If the latter is the case, it might consolidate our hypothesis on the antioxidant action of the porcine splenic hydrolysate in the gastrointestinal tract.

In conclusions, the present study demonstrated that the porcine splenic hydrolysate improved antioxidant activity both in vivo and in vitro via a potential mechanism that might involve radical scavenging activity. In future, the safety of porcine splenic peptides with regard to toxicity and allergenicity remains to be determined.

\section{Acknowledgements}

The authors wish to thank Mr. Koudai Semba and Mr. Kyouichi Machida (Department of Food Science, Obihiro University of Agriculture and Veterinary Medicine) for technical assistance and Mr. Yoshihisa Takahata (Nipponham R\&D Center, Nippon Meat Packers) for supporting materials. This research was carried out with the support of a grant from the Regional Innovation Cluster Program (City Area Type) of the Ministry of Education, Culture, Sports, Science, and Technology of Japan.

\section{References}

1. Aebi, H. (1984) Catalase in vitro. Methods Enzymol. 105, 121-126.

2. AOAC (1990) Official Mmethods of analysis. 15th ed, Association of Official Analytical Chemists, Washington, DC.

3. Bae, J. H., Bassenge, E., Kim, K. B., Kim, Y. K., Kim, K. S., Lee, H. J., Moon, K. C., Lee, M. S., Park, K. Y., and Schwemmer, M. (2001) Postprandial hypertriglyceridemia impairs endothelial function by enhanced oxidant stress. Atherosclerosis 155, 517-523.

4. Borghardt, J., Rosien, B., Görtelmeyer, R., Lindemann, S., Hartleb, M., and Klingmüller, M. (2000) Effects of a spleen peptide preparation as supportive therapy in inoperable head and neck cancer patients. Arzneimittelforschung 50, 178-184.

5. Brand-Williams, W., Cuvelier, M. E., and Berset, C. (1995) Use of a free radical method to evaluate antioxidant activity. LWT-Food Sci. Technol. 28, 25-30.

6. Cadenas, E. and Davies, K. J. (2000) Mitochondrial free radical generation, oxidative stress, and aging. Free Radic. Biol. Med. 29, 222-230.

7. Cohn, V. H. and Lyle, J. A. (1966) Fluorometric assay for glutathione. Anal. Biochem. 14, 434-440.

8. Dávalos, A., Miguel, M., Bartolomé, B., and López-Fandiño, R. (2004) Antioxidant activity of peptides derived from egg white proteins by enzymatic hydrolysis. J. Food Prot. 67, 1939-1944.

9. Di Bernardini, R., Mullen, A. M., Bolton, D., Kerry, J., O' Neill, E., and Hayes, M. (2012) Assessment of the angiotensinI-converting enzyme (ACE-I) inhibitory and antioxidant activities of hydrolysates of bovine brisket sarcoplasmic proteins produced by papain and characterisation of associated bioactive peptidic fractions. Meat Sci. 90, 226-235.

10. Dinis, T. C. P., Madeira, V. M. C., and Almeida, L. M. (1994) Action of phenolic derivatives (acetaminophen, salicylate, and 5-aminosalicylate) as inhibitors of membrane lipid peroxidation and as peroxyl radical scavengers. Arch. Biochem. Biophys. 315, 161-169.

11. Dong, S., Wei, B., Chen, B., McClements, D. J., and Decker, E. A. (2011) Chemical and antioxidant properties of casein peptide and its glucose Maillard reaction products in fish oilin-water emulsions. J. Agric. Food Chem. 59, 13311-13317.

12. Elias, R., Kellerby, S. S., and Decker, E. A. (2008) Antioxidant activity of proteins and peptides. Crit. Rev. Food Sci. Nutr. 48, 430-441.

13. Fitzgerald, R. J. and Murray, B. A. (2006) Bioactive peptides and lactic fermentation. Int. J. Dairy Technol. 59, 118-125.

14. Fujiwara, M., Ishida, Y., Nimura, N., Toyama, A., and Kinoshita, T. (1987) Postcolumn fluorometric detection system for liquid chromatographic analysis of amino and imino acids using o-phthalaldehyde/N-acetyl-L-cysteine reagent. Anal. Biochem. 166, 72-78.

15. Gardner, M. L. G. (1988) Gastrointestinal absorption of intact proteins. Annu. Rev. Nutr. 8, 329-350.

16. Gill, I., López-Fandino, R., Jorba, X., and Vulfson, E. (1996) Biologically active peptides and enzymatic approaches to their 
production. Enzyme Microb. Technol. 18, 162-183.

17. Habig, W. H., Pabst, M. J., and Jakoby. W. B. (1974) Glutathione-S-transferases. J. Biol. Chem. 249, 7130-7139.

18. Halliwell, B., Zhao, K., and Whiteman, M. (2000) The gastrointestinal tract: a major site of antioxidant action? Free Radic. Res. 33, 819-830.

19. Hernandez-Ledesma, B., Dávalos, A., Bartolomé, B., and Amigo, L. (2005) Preparation of antioxidant enzymatic hydrolysates from alpha-lactalbumin and beta-lactoglobulin, Identification of active peptides by HPLC-MS/MS. J. Agric. Food Chem. 53, 588-593.

20. Horiguchi, N., Horiguchi, H., and Suzuki, Y. (2005) Effect of wheat gluten hydrolysate on the immune system in healthy human subjects. Biosci. Biotechnol. Biochem. 69, 2445-2449.

21. Korhonen, H. and Pihlanto, A. (2003) Food-derived bioactive peptides-opportunities for designing future foods. Curr. Pharm. Des. 9, 1297-1308.

22. Latham, P. W. (1999) Therapeutic peptides revisited. Nat. Biotechnol. 17, 755-757.

23. Lawrence, R. and Burk, R. (1976) Glutathione peroxidase activity in selenium-deficient rat liver. Biochem. Biophys. Res. Commun. 7, 952-958.

24. López-Alarcón, C. and Lissi, E. (2005) Interaction of pyrogallol red with peroxyl radicals. A basis for a simple methodology for the evaluation of antioxidant capabilities. Free Radic. Res. 39, 729-736.

25. Nazeer, R. A., Sampath Kumar, N. S., and Jai Ganesh, R. (2012) In vitro and in vivo studies on the antioxidant activity of fish peptide isolated from the croaker (Otolithes ruber) muscle protein hydrolysate. Peptides 35, 261-268.

26. Ohkawa, H., Ohishi, N., and Yagi, K. (1979) Assay for lipid peroxide in animal tissues by thiobarbutric reactions. Anal. Biochem. 95, 351-358.

27. Rival, S. G., Boeriu, C. G., and Wichers, H. J. (2001) Casein and casein hydrolysates. 1. Lipoxygenase inhibitory properties. J. Agric. Food Chem. 49, 287-294.

28. Saiga, A., Soichi, T., and Nishimura, Y. (2003) Antioxidant activity of peptides from porcine myofibrillar proteins by protease treatment. J. Agric. Food Chem. 51, 3661-3667.

29. Sies, H., Stahl, W., and Sevanian, A. (2005) Nutritional, dietary and postprandial oxidative stress. J. Nutr. 135, 969-972.

30. Stahl, W., van den Berg, H., Arthur, J., Bast, A., Dainty, J., Faulks, R. M., Gärtner, C., Haenen, G., Hollman, P., Holst, B., Kelly, F. J., Polidori, M. C., Rice-Evans, C., Southon, S., van Vliet, T., Viña-Ribes, J., Williamson, G., and Astley, S. B. (2002) Bioavailability and metabolism. Mol. Asp. Med. 23, 39-100.

31. Udenigwe, C. C. and Howard, A. (2012) Meat proteome as source of functional biopeptides. Food Res. Int. 54, 10211032.

32. Wang, H. L. and Kurtz, A. (2000) Breast cancer growth inhibition by delivery of the MDGI-derived peptide P108. Oncogene 19, 2455-2460.

33. Worthington, D. J. and Rosemeyer, M. A. (1976) Glutathione reductase from human erythrocytes, Catalytic properties and aggregation. Eur. J. Biochem. 67, 231-238.

(Received 2014.3.13/Revised 2014.4.28/Accepted 2014.4.29) 